\title{
Effect of Helicobacter pylori eradication on gastric emptying and symptoms in patients with dyspepsia
}

\author{
Wpływ eradykacji zakażenia Helicobacter pylori na opróżnianie żołądka \\ u pacjentów z dyspepsją
}

\author{
Marek Waluga ${ }^{1}$, Krzysztof Jonderko $^{2}$, Beata Krusiec-Świdergoł², Magdalena Kamińska², \\ Anna Kasicka-Jonderko², Magdalena Lesińska ${ }^{1}$ \\ 1Department of Gastroenterology and Hepatology, Medical University of Silesia, Katowice, Poland \\ 2Department of Basic Biomedical Sciences, Medical University of Silesia, Sosnowiec, Poland
}

Przegląd Gastroenterologiczny 2011; 6 (2): 118-124

DOI: $10.5114 / p g .2011 .21722$

Key words: ${ }^{13} \mathrm{C}$-octanoic acid breath test, dyspepsia, eradication, gastric emptying, Helicobacter pylori.

Słowa kluczowe: test oddechowy z ${ }^{13} \mathrm{C}$ kwasem oktanowym, dyspepsja, eradykacja, opróżnianie żołądka, Helicobacter pylori.

Address for correspondence: Marek Waluga, MD, PhD, Department of Gastroenterology and Hepatology, Silesian Medical University, Medyków 14, 40-752 Katowice, Poland, phone +48 3278944 01, fax +48 3278944 02, e-mail: marek.waluga@neostrada.pl

\begin{abstract}
Aim: To study whether eradication of Helicobacter pylori (H. pylori) in patients with functional dyspepsia affects gastric emptying (GE) and concomitantly relieves their clinical symptoms.

Material and methods: Eighteen $H$. pylori-positive patients suffering from functional dyspepsia were recruited. At entrance and two weeks after successful $H$. pylori eradication they filled in a questionnaire examining the intensity of dyspeptic symptoms and underwent measurement of GE of a $378 \mathrm{kcal}$ solid test meal labelled with $75 \mu \mathrm{l}$ of ${ }^{13} \mathrm{C}$-octanoic acid. Normative values of GE were obtained in 12 healthy controls.

Results: Helicobacter pylori eradication was attained in 17 patients. The duration of the lag phase ( $T_{-} L a g$ ) of the GE did not change after the eradication (mean \pm SD $144.5 \pm 23.2 \mathrm{~min}$ ) vs. before the eradication $(152.1 \pm 27.6 \mathrm{~min})$. On the other hand, the gastric half emptying time $\left(T_{1 / 2}\right)$ increased statistically significantly from $207.1 \pm 33.5 \mathrm{~min}$ before eradication to $229.5 \pm 49.4 \mathrm{~min}(p=0.0217)$. Considering the whole patient group, the $H$. pylori eradication did not significantly affect the dyspeptic symptoms. It was established, however, that the deterioration of the score for fullness or satiety was dependent on the increase in the T_Lag. Also the aggravation of pain, burning or satiety was related to the prolongation of the $T_{1 / 2}$. Conclusions: 1) Eradication of $\mathrm{H}$. pylori in patients with functional dyspepsia prolongs the gastric half emptying time of a solid meal without eliciting a significant symptomatic improvement. 2) The worsening of dyspeptic symptoms may be related to sluggish gastric emptying.
\end{abstract}

\section{Streszczenie}

Cel: Ustalenie, czy eradykacja Helicobacter pylori (H. pylori) u chorych z dyspepsją czynnościową wpływa na szybkość opróżniania żołądka (gastric emptying - GE) i złagodzenie towarzyszących objawów klinicznych.

Materiał i metody: W badaniu wzięło udział 18 chorych z infekcją H. pylori cierpiących na dyspepsję czynnościową. W czasie włączania do badania oraz 2 tyg. po skutecznej eradykacji wypełniali oni kwestionariusz mający na celu określenie nasilenia objawów dyspeptycznych oraz zostali poddani pomiarowi GE z positku stałego o wartości energetycznej $378 \mathrm{kcal} \mathrm{z}$ dodatkiem $75 \mu \mathrm{l}{ }^{13} \mathrm{C}$-kwasu oktanowego. Wartości normatywne kinetyki GE wyznaczono u 12 zdrowych osób. Wyniki: Eradykację H. pylori uzyskano u 17 chorych. Czas trwania fazy opóźnienia GE (T_Lag) nie zmienił się po eradykacji (średnia \pm SD 144,5 $\pm 23,2$ min) w porównaniu z czasem przed eradykacją (152,1 $\pm 27,6 \mathrm{~min})$. Półokres $\mathrm{GE}\left(\mathrm{T}_{1 / 2}\right)$ natomiast zwiększył się statystycznie znamiennie z 207,1 $\pm 33,5$ min przed eradykacją do $229,5 \pm 49,4$ min po eradykacji $(p=0,0217)$. Biorąc pod uwagę całą grupę chorych, eradykacja $H$. pylori nie wpłynęła znamiennie na objawy dyspeptyczne. Wykazano jednak, że pogorszenie punktacji w skali oceny uczucia pełności lub wczesnej sytości zależało od wzrostu długości T_Lag, podczas gdy zwiększenie odczucia bólu, pieczenia i pełności od wydłużenia $T_{1 / 2}$.

Wnioski: 1) Eradykacja H. pylori u chorych z dyspepsją czynnościową wydłuża półokres opróżniania żołądka z pokarmów stałych, nie wywierając znamiennego wpływu na zmniejszenie objawów. 2) Pogorszenie objawów dyspeptycznych może się wiązać ze zwolnionym opróżnianiem żołądka. 


\section{Introduction}

Dyspepsia is a clinical syndrome that occurs very commonly in the general population. In Europe, it accounts for almost a third of all gastroenterological referrals and up to a quarter of all general practitioners' consultations [1]. In most of the patients with chronic dyspepsia even a thorough medical examination does not provide a definite anatomical or biochemical explanation for their symptoms and therefore they will be classified as suffering from functional dyspepsia (FD) [2]. Moreover, some patients with FD also have concomitant symptoms of irritable bowel syndrome [1]. Although FD is not a life-threatening disease, it is an important morbid entity because of the poor quality of life of affected individuals.

A FD is considered a heterogeneous disorder with different pathophysiological mechanisms contributing to the symptom pattern. Recently the Rome III criteria for the diagnosis of FD were established. The definition of FD includes upper abdominal pain, burning sensation, epigastric fullness and early feeling of satiety. Several mechanisms have been proposed for the pathogenesis of FD: acid hypersecretion, delayed gastric evacuation, visceral hypersensitivity, psychological factors or stress, or Helicobacter pylori (H. pylori) infection [1, 3]. $H$. pylori infection may also play a role in the pathogenesis of functional dyspepsia [4].

Motility-related mechanisms have been suspected to underlie the symptoms presented by FD patients, e.g. the sequelae of defective gastroduodenal motor function, such as impaired gastric fundus accommodation and/or abnormal antral distension, as well as changes in gastric emptying (GE) kinetics [3].

Many techniques have been developed over the decades to study the GE speed in humans. Although dynamic scintigraphy is still considered as the gold standard, currently several other techniques of $\mathrm{GE}$ measurement are in use, e.g. applied potential tomography, acetaminophen absorption test, or ultrasonography [5]. Lately ${ }^{13} \mathrm{CO}_{2}$ breath tests accomplished with the use of ${ }^{13} \mathrm{C}$-octanoic acid or ${ }^{13} \mathrm{C}$-sodium acetate for labelling the solid or liquid phase of the meal, respectively, have come out at the top of the methodological armoury serving for the GE examination [6]. These breath tests, although they constitute an indirect approach to measure GE of solids or liquids, yield results comparable with radioscintigraphy. They are harmless, noninvasive, and easy to perform, even in elderly or disabled patients. Accordingly, repeated GE studies with breath tests involving the stable ${ }^{13} \mathrm{C}$ isotope are entirely acceptable even in children and pregnant women [7-9].

\section{Aim}

The aim of this study was to check if eradication of H. pylori would elicit changes in the kinetics of the GE of solids and whether those changes, if any, would affect the symptoms of dyspepsia.

\section{Material and methods}

\section{Subjects}

A total of 18 patients ( 13 females and 5 males, mean age $42.1 \pm 9.9$ years) with functional dyspepsia and H. pylori infection were recruited to enter the study. Every patient presented one or more symptoms coherent with the Rome III diagnostic criteria of FD: upper abdominal pain, burning sensation, fullness, early feeling of satiety [10]. Endoscopic examination of the upper part of the gastrointestinal tract excluded an organic disease and quick urease test using biopsy specimens confirmed $H$. pylori infection in each patient. History questioning and routine medical evaluation excluded organic diseases which might affect gastrointestinal motility. Exclusion criteria comprised current use of any drugs, a history of abdominal surgery except for appendectomy, and pregnancy. The study was approved by the Bioethics Committee of the Silesian Medical University. Examinations were conducted in accordance with the Helsinki Declaration. Each patient gave written consent to participate after receiving information as to the aim, protocol and methodology of the study.

\section{Experimental protocol}

Every patient defined the intensity of the symptoms of FD (upper abdominal pain, burning sensation, fullness and early feeling of satiety) with the use of a 4-score scale (0 - without symptoms, 1 - weak, 2 - mild, 3 severe) and filling in a questionnaire before and after eradication.

The patients underwent two sessions of the GE measurement - the first one was performed a few days after the endoscopic examination and the second one after completion of the $H$. pylori eradication treatment.

The following algorithm of taking the biopsy on endoscopy was adopted: (1) for the detection of H. pylo$r i$ infection three specimens (from the angle, antrum and corpus along the greater curvature) were obtained for the rapid urease test, (2) three more specimens (one from the corpus and two from the antrum) were collected for the histopathological examination which was accomplished in accordance with the Sydney system. Only patients without or with only minimal histopathological changes were included in the study. 
For the eradication of $H$. pylori a four-drug combination therapy was applied which consisted of omeprazole $20 \mathrm{mg}$, amoxicillin $1 \mathrm{~g}$, clarithromycin $0.5 \mathrm{~g}$ and metronidazole $0.5 \mathrm{~g}$ - each drug being administered twice daily for 7 days except for omeprazole which was administered for 10 days. Two weeks after completion of the treatment a standard breath test with ${ }^{13} \mathrm{C}$-urea [11] was performed in order to check the $H$. pylori status. If the eradication was successful the end-point GE measurement was performed and the questionnaire for evaluation of dyspeptic symptoms was filled in.

The GE measurement was performed with the subjects in a sitting position after a 12-h overnight fast. After collection of a basal fasted probe of the exhaled air the subjects ate within no more than 10 min a solid test meal - a pancake smeared with strawberry jam (1574 kJ [378 kcal]; $15.5 \mathrm{~g}$ proteins, $16.8 \mathrm{~g}$ fat, and $43.0 \mathrm{~g}$ carbohydrates) [9]. During the preparation procedure of the pancake two egg yolks were temporarily separated from the egg whites and thoroughly mixed with $75 \mu \mathrm{l}$ (68 mg) of ${ }^{13}$ C-octanoic acid (INC610P, lot \#T012A-L3241, Euriso-Top, France) which was instilled using a precision digital micropipette (Calibra 822-20/200, Socorex, Switzerland). $200 \mathrm{ml}$ of still mineral water was allowed as a drink. Counting the passage of time from the start of the meal intake, a total of 26 probes of the expiratory air were collected postprandially: every 10 min during the $1^{\text {st }} \mathrm{h}$, and subsequently every $15 \mathrm{~min}$ for another $5 \mathrm{~h}$; the probes were collected into aluminium covered plastic bags of about 1 I capacity (Fischer Analysen Instrumente $\mathrm{GmbH}$, Germany). During the postprandial period the subjects were asked not to take any additional food or drink for $6 \mathrm{~h}$. They were allowed to rest sitting in a comfortably furnished room and allowed to watch video films.

\section{Measurement of ${ }^{13} \mathrm{CO}_{2}$ and derivation} of gastric emptying parameters

The enrichment of ${ }^{13} \mathrm{CO}_{2}$ in the probes of exhaled air was measured using non-dispersive isotope-selective infrared spectrometry (IRIS apparatus manufactured by Wagner AnalysenTechnik Vertriebs GmbH, Germany; a model equipped with 16 ports for simultaneous mounting of bags with air samples was used). Using algorithms of non-linear regression implemented in the Statistica 6.1 software [12], the curves of momentary ${ }^{13} \mathrm{C}$ recovery within the exhaled air were fitted to the function:

$$
\mathrm{D} \%{ }_{\mathrm{i}_{-}}{ }^{13} \mathrm{C}=a \mathrm{t}^{b} \mathrm{e}^{-c t},
$$

where $t$ stands for time, and $a, b, c$ are parameters of the function which enabled computation of the GE parameters:
(1) the lag phase, T_Lag $=b / c$

(2) the gastric half emptying time, $T_{1 / 2}=$

= Gamma inv. $(0.5 ; b+1 ; 1 / c)$ [9].

\section{Determination of the normal range of the gastric emptying parameters}

The control GE data were obtained in 12 healthy volunteers ( 6 females and 6 men, mean age $24.9 \pm 2.4$ years) who participated in a reproducibility study [9]. In every one of them the GE measurement was taken on three separate days. Subsequently the averages of the three measurement results were used to calculate the normative values of the GE parameters.

\section{Statistical analysis}

All statistical analyses were performed using Statistica 6.1 software [12]. Parametric or non-parametric statistical tests were applied where appropriate. Results are presented as means \pm SD.

\section{Results}

The $H$. pylori eradication was successful in 17 patients and in 1 failed; hence the success rate of the four-drug therapy was $94.4 \%$. The only patient with persistent $H$. pylori infection was excluded from the next steps of the study.

The normative values of the parameters quantitatively characterizing the GE of the solid meal established in the control group were $146.7 \pm 16.0 \mathrm{~min}$ ( $T_{-}$Lag) and $201.2 \pm 15.7 \mathrm{~min}\left(T_{1 / 2}\right)$.

In the patients the mean T_Lag was $144.5 \pm 23.2 \mathrm{~min}$ and $152.1 \pm 27.6 \mathrm{~min}$ before and after eradication respectively; the difference between these values was not statistically significant. On the other hand, the $T_{1 / 2}$ increased statistically significantly from $207.1 \pm 33.5 \mathrm{~min}$ before eradication to $229.5 \pm 49.4 \mathrm{~min}$ ( $p=0.0217$ ).

Individual results regarding the GE kinetics are displayed in Figure 1 and Figure 2, whereas in Table I the patients' ratings of dyspeptic symptoms are aggregated.

A closer look at these data reveals a relationship between the change of intensity of subjective complaints and the observed shifts of GE kinetics.

With regard to the duration of the T_Lag, two patients had it longer than the mean +2 SD of the healthy controls (Figure 1). In one of them the T_Lag remained almost the same after eradication. This patient had the highest grade (severe $=$ score 3 ) of fullness and satiety within the whole group either before or after the eradication. In the other patient the abnormally long T_Lag decreased towards the mean value of healthy controls after the eradication. He defined his symptoms 
as mild (score 2) before and weak (score 1) after the eradication. Similarly, one patient had the T_Lag within the normal range before the eradication and the longest among the whole group after the eradication. This patient defined his ailment as weak (score 1) before the eradication and as mild (score 2 ) thereafter.

A formal analysis revealed next a statistically significant relationship between either the net changes in the score for fullness and the net T_Lag changes (Spearman $r=0.661, p=0.0039$ ), or the net changes in the score for satiety and the net T_Lag changes (Spearman $r=0.710, p=0.0014)$. Hence the deterioration of the score for fullness or satiety was dependent on the increase in the T_Lag. The net changes in the scores for pain and burning were unrelated to the T_Lag changes - the Spearman $r$ was $0.331(p=0.19)$ and 0.212 $(p=0.41)$, respectively.

Taking into consideration the $T_{1 / 2}$, three patients exhibited it longer than mean +2 SD of the healthy controls before the eradication (Figure 2). In two of them the $T_{1 / 2}$ continued to be prolonged after the eradication. Their ailments such as pain and burning were mild (score 2) either before or after the eradication, and fullness and satiety even increased from weak (score 1) to mild (score 2). We observed that in three patients whose $T_{1 / 2}$ was within the normal range before the eradication it appeared to be severely prolonged after the eradication, exceeding the limit of the mean +2 SD established in the controls. Remarkably, the ailments of pain and burning increased from weak (score 1) to mild (score 2) in two of them, although fullness and satiety dropped from mild (score 2) to weak (score 1).

Consequently a statistically significant relationship was disclosed between: the net changes in the score for pain and the net $T_{1 / 2}$ changes (Spearman $r=0.608$, $p=0.0097)$, the net changes in the score for burning and the net $T_{1 / 2}$ changes (Spearman $r=0.546$, $p=0.0234$ ), and net changes in the score for satiety and the net $T_{1 / 2}$ changes (Spearman $r=0.560, p=$ 0.0193). Accordingly the aggravation of pain, burning or satiety was related to the prolongation of the $T_{1 / 2}$. Solely the net changes in the score for fullness did not statistically significantly correlate with the $T_{1 / 2}$ changes (Spearman $r=0.448, p=0.0714$ ).

\section{Discussion}

A delayed GE in patients suffering from FD was found with an incidence that varies from $15 \%$ to $50 \%$ of cases [13]; therefore it is a non-specific disease marker [14]. Inversely, according to observations of Stanghellini et al. certain dysmotility symptoms and their severity were strong risk indicators fora delayed GE [15].

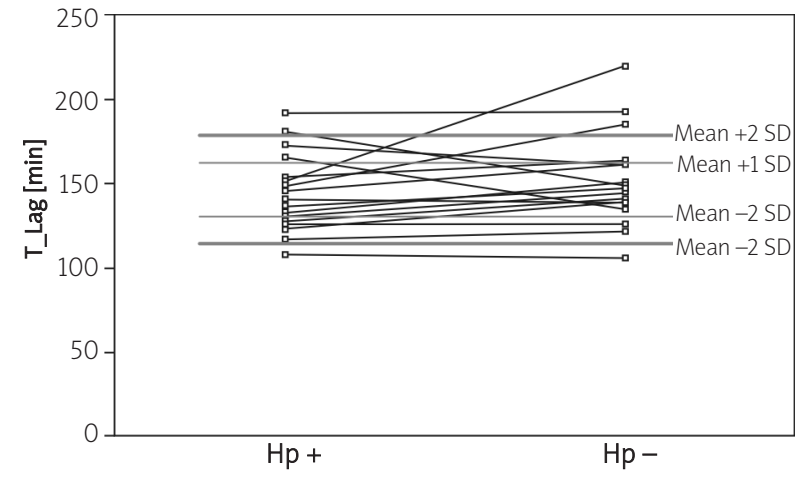

Fig. 1. Individual changes in the duration of the lag phase (T_Lag) of the gastric emptying a solid meal observed in 17 patients with functional dyspepsia before $(\mathrm{Hp}+)$ and after successful H. pylori eradication ( $\mathrm{Hp}-$ ). The horizontal lines delimit the T_Lag ranges established in 12 healthy controls

Ryc. 1. Indywidualne zmiany długości fazy opóźnienia (T_Lag) opróżniania żołądka z pokarmu stałego obserwowane u 17 chorych z czynnościowa dyspepsja przed skuteczna eradykacja H. pylori $(\mathrm{Hp}+$ ) i po niej ( $\mathrm{Hp}-)$. Linie poziome wyznaczaja granice zakresu wartości prawidtowych ustalonego u 12 zdrowych osób

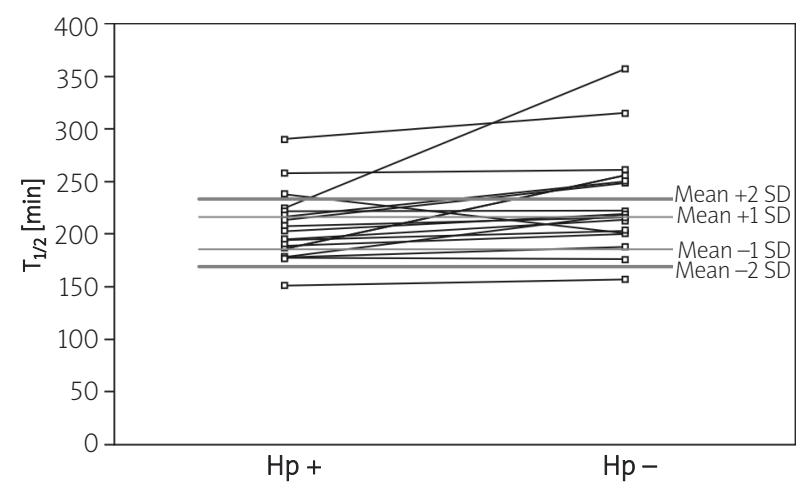

Fig. 2. Individual changes in the duration of the gastric half emptying time $\left(T_{1 / 2}\right)$ of a solid meal observed in 17 patients with functional dyspepsia before $(\mathrm{Hp}+)$ and after successful H. pylori eradication ( $\mathrm{Hp}-$ ). The horizontal lines delimit the $T_{1 / 2}$ ranges established in 12 healthy controls Ryc. 2. Indywidualne zmiany długości półokresu opróżniania żołądka ( $\left.T_{1 / 2}\right)$ z pokarmu statego obserwowane u 17 chorych z czynnościowa dyspepsja przed skuteczna eradykacja H. pylori $(\mathrm{Hp}+)$ i po niej (Hp-). Linie poziome wyznaczaja granice zakresu wartości prawidłowych ustalonego u 12 zdrowych osób 
Table I. Dyspeptic symptoms self-evaluated with a 4-score scale $(0=$ without symptoms, $1=$ weak, $2=$ mild, $3=$ severe) before and after $H$. pylori eradication in patients with functional dyspepsia

Tabela I. Objawy dyspeptyczne podlegające samoocenie $w$ 4-stopniowej skali ( 0 = bez objawów, objawy: 1 = niewielkie, 2 = umiarkowane, 3 = znacznie nasilone) przed eradykacja H. pylori i po niej u chorych z czynnościową dyspepsją

\begin{tabular}{|c|c|c|c|c|c|c|c|c|}
\hline \multirow[t]{2}{*}{ Patient } & \multicolumn{4}{|c|}{ Before eradication } & \multicolumn{4}{|c|}{ After eradication } \\
\hline & pain & burning & fullness & satiety & pain & burning & fullness & satiety \\
\hline ZW & 1 & 1 & 1 & 1 & 1 & 1 & 2 & 2 \\
\hline KB & 2 & 2 & 3 & 3 & 3 & 3 & 3 & 3 \\
\hline ZJ & 1 & 1 & 1 & 1 & 1 & 1 & 1 & 1 \\
\hline KM & 2 & 2 & 1 & 1 & 2 & 2 & 2 & 2 \\
\hline MA & 2 & 2 & 1 & 1 & 2 & 2 & 2 & 2 \\
\hline$J Z$ & 1 & 1 & 1 & 1 & 1 & 1 & 1 & 1 \\
\hline SM & 2 & 2 & 2 & 2 & 1 & 1 & 1 & 1 \\
\hline $\mathrm{tH}$ & 1 & 1 & 2 & 1 & 2 & 2 & 2 & 2 \\
\hline $\mathrm{KG}$ & 1 & 2 & 1 & 1 & 2 & 2 & 2 & 1 \\
\hline$G D$ & 1 & 1 & 1 & 1 & 1 & 1 & 1 & 1 \\
\hline SW & 1 & 1 & 2 & 2 & 2 & 2 & 1 & 1 \\
\hline SA & 1 & 1 & 1 & 1 & 1 & 1 & 1 & 1 \\
\hline LJ & 1 & 1 & 1 & 1 & 1 & 1 & 2 & 1 \\
\hline $\mathrm{KP}$ & 1 & 1 & 2 & 2 & 2 & 2 & 1 & 1 \\
\hline KK & 3 & 2 & 2 & 2 & 1 & 1 & 1 & 1 \\
\hline SK & 1 & 1 & 1 & 1 & 1 & 1 & 1 & 1 \\
\hline NA & 1 & 1 & 1 & 1 & 1 & 1 & 1 & 1 \\
\hline
\end{tabular}

Statistical analysis did not reveal any significant difference between the corresponding scores before and after the H. pylori eradication

Published data support the contention that delayed GE is not a cause of dyspepsia. The most convincing proof is that an improvement of GE does not usually correlate with the symptomatic relief of dyspepsia. Kellow et al. tested cisapride versus placebo in 61 patients with functional dyspepsia and there was no symptom improvement in a subgroup with delayed GE [16]. Talley et al. demonstrated in a large cohort study of patients with functional and organic dyspepsia, characterized by postprandial distress, that neither the presence nor the severity of symptoms was a reliable predictor of delayed GE [17].

Helicobater pylori infection may be associated with an alteration in gastric motility during fasting [18], while after a meal normal or accelerated GE was observed [19]. Gastric antral inflammation, independently of H. pylori infection, may induce smooth muscle alteration and consequently delayed emptying [20]. A tendency towards delayed GE among dyspeptic patients, but only a minor association between GE speed and the symptoms of dyspepsia, was described [17, 21]. In the study performed by Koskenpato et al., dyspeptic patients ten- ded to have a prolonged GE of solids, although the difference vs. healthy controls was not statistically significant [21]. In a previous study of this research group the effect of $H$. pylori seemed to be less important in multivariate analysis than some other factors [22].

Some studies reported on changes in GE after H. pylori eradication. Kachi et al. [8], as well as Miyaji et al. [23], reported that GE was improved by $H$. pylori eradication in patients with initially disturbed gastric evacuation. On the other hand, Koskenpato et al. did not observe statistically significant differences in GE between $H$. pylori-eradicated and placebo-treated patients after 1 year [21]. Tucci et al. reported that although generally GE was not changed after $H$. pylori eradication, some patients with delayed GE at entry had normal GE after eradication [24].

Konturek et al. found that in duodenal ulcer patients $H$. pylori infection is accompanied by an accelerated GE and that eradication of $H$. pylori decreases the emptying rate to the level observed in healthy subjects [25]. It is worth pointing out that the results of our study, although performed on a different patient group, are entirely 
in agreement with the findings of Konturek et al. because we too observed a delay of GE after $\mathrm{H}$. pylori eradication.

Interestingly, in our study we found that the changes of intensity of symptoms inherent to FD bear a relationship to the shifts of GE speed. It was established that the deterioration of the score for fullness or satiety was dependent on the increase in the T_Lag. Also the aggravation of pain, burning or satiety was related to the prolongation of the $T_{1 / 2}$. One should be aware, however, that within the whole group of our patients these relationships did not appear to be close. For example, the relationship between the net changes in the score for pain and the net $T_{1 / 2}$ changes was characterized by a modest Spearman correlation coefficient of 0.608 . Similarly, the association between the net changes in the score for satiety and the net T_Lag changes had a modest Spearman correlation coefficient of 0.710 . Nevertheless, our findings are in agreement with, and at the same time provide further support for, the current view that within the cohort of FD patients a subset can be identified which is characterized by a dependence of pain on the impaired motor function of the stomach, whereas in other subgroups the origin of pain has to be linked to motility unrelated causes.

\section{Conclusions}

Summing up, the results of the study justify the following conclusions: (1) Eradication of $H$. pylori in patients with functional dyspepsia prolongs the gastric half emptying time of a solid meal without eliciting a significant symptomatic improvement. (2) The worsening of dyspeptic symptoms may be related to sluggish gastric emptying.

\section{Acknowledgements}

Financial support of the project was provided by the Medical University of Silesia (contract NN-1-168/07).

\section{References}

1. Perri F, Clemente R, Festa V. Patterns of symptoms in functional dyspepsia: role of Helicobacter pylori infection and delayed gastric emptying. Am J Gastroenterol 1998; 93: 2082-8.

2. Talley NJ, Colin-Jones DG, Koch KL, et al. Functional dyspepsia: a classification with guidelines for diagnosis and management. Gastroenterol Int 1991; 4: 145-60.

3. Funch-Jensen P, Talley NJ, Drossman A, et al. Functional dyspepsia. Eur J Gastroenterol Hepatol 1992; 4: 595-625.

4. Karamanolis G, Caenepeel P, Arts J, et al. Association of the predominant symptom with clinical characteristics and pathophysiological mechanisms in functional dyspepsia. Gastroenterology 2006; 130: 296-303.

5. Jonderko K. Radioisotope determination of gastric emptying Probl Med Nukl 1989; 3: 8-16.
6. Doe-Young K, Camilleri M. Stable isotope breath test and gastric emptying. In: Schuster atlas of gastrointestinal motility in health and disease. $2^{\text {nd }}$ Ed. Schuster MM, Crowell MD, Koch KL (eds.). BC Decker Inc., Hamilton, London 2002; 203-18.

7. Chin-Ping C, Chin-Yen C, Ching-Liang L, et al. Gastric function abnormalities. J Gastroenterol Hepatol 2003; 18: 41-6.

8. Kachi M, Shirasaka D, Aoyama N, et al. Effects of Helicobacter pylori eradication therapy on gastric emptying measured using ${ }^{13} \mathrm{C}$-octanoic acid breath test and acetaminophen method. J Gastroent Hepatol 2006; 21: 824-30.

9. Kasicka-Jonderko A, Kamińska M, Jonderko K, et al. Short- and medium-term reproducibility of gastric emptying of a solid meal determined by a low dose of ${ }^{13} \mathrm{C}$-octanoid acid and nondispersive isotope-selective infrared spectrometry. World J Gastroenterol 2006; 12: 1243-8.

10. Drossman DA. Rome III: The new criteria. Chin J Dig Dis 2006; 7: 181-5.

11. Braden B, Schafer F, Caspary WF, et al. Nondispersive isotopeselective infrared spectroscopy: a new analytical method for ${ }^{13}$ C-urea breath tests. Scand J Gastroenterol 1996; 31: 442-5.

12. StatSoft, Inc. Electronic statistics textbook, StatSoft WEB. Tulsa, OK. 2007. http://www.statsoft.com/textbook/stathome. html.

13. Waldron B, Cullen PT, Kumar R, et al. Evidence for hypomotility in non-ulcer dyspepsia: a prospective multifactorial study. Gut 1991; 32: 246-51.

14. Stanghellini V, Tosetti C, Paternico A, et al. Predominant symptoms identify different subgroups in functional dyspepsia. Am J Gastroenterol 1999; 94: 2080-5.

15. Stanghellini V, Tosetti C, Paternico A, et al. Risk indicators of delayed gastric emptying of solids in patients with functional dyspepsia. Gastroenterology 1996; 110: 1036-42.

16. Kellow JE, Cowan H, Shuter B, et al. Efficacy of cisapride therapy in functional dyspepsia. Aliment Pharmacol Ther 1995; 9: 153-60.

17. Talley NJ, Shuter B, McCrudden G, et al. Lack of association between gastric emptying of solids and symptoms in nonulcer dyspepsia. J Clin Gastroenterol 1989; 11: 625-30.

18. Testoni PA, Bagnolo F, Masci E, et al. Different interdigestive antroduodenal motility patterns in chronic antral gastritis with and without Helicobacter pylori infection. Dig Dis Sci 1993; 38: 2255-61.

19. Caldwell SH, Valenzuela G, Marshall BJ, et al. Helicobacter pylori infection and gastric emptying of solids in humans. J Gastrointest Motil 1992; 4: 113-7.

20. Marzio L, Falcucci M, Ciccaglione AF, et al. Relationship between gastric and gallbladder emptying and refilling in normal subjects and patients with $\mathrm{H}$. pylori positive and negative idiopathic dyspepsia and correlation with symptoms. Dig Dis Sci 1996; 41: 26-31.

21. Koskenpato J, Korppi-Tommola T, Kairemo K, et al. Long-term follow-up study of gastric emptying and Helicobacter pylori eradication. Dig Dis Sci 2000; 45: 1763-8.

22. Koskenpato J, Kairemo K, Korppi-Tommola T, et al. The role of gastric emptying in functional dyspepsia - a scintigraphic study of 94 patients. Dig Dis Sci 1998; 43: 1154-8.

23. Miyaji H, Azuma T, Ito S, et al. The effect of Helicobacter pylori eradication therapy on gastric antral myoelectrical activity 
and gastric emptying in patients with non-ulcer dyspepsia. Aliment Pharmacol Ther 1999; 13: 1473-80.

24. Tucci A, Poli L, Tosetti C, et al. Reversal of fundic atrophy after eradication of Helicobacter pylori. Am J Gastroenterol 1998; 93: 1425-31.

25. Konturek JW, Stoll R, Menzel J, et al. Eradication of Helicobacter pylori restores the inhibitory effect of cholecystokinin on gastric motility in duodenal ulcer patients. Scand I Gastroenterol 2001; 36: 241-6. 